\title{
The Financial Status of Community Pharmacies: Çorum Province
}

\section{Toplum Eczanelerinin Mali Durumu: Çorum İli Örneği}

\author{
(1) Sıdıka Öznur SAKINÇ'1, (1) Emrah BILGENER2* \\ ${ }^{1}$ Hitit University Vocational School of Social Sciences, Department of Management and Organization, Çorum, Turkey \\ 2 Hitit University Faculty of Health Sciences, Department of Health Economics, Division of Healthcare Management, Çorum, Turkey
}

\begin{abstract}
Objectives: Community pharmacies have financial difficulties due to reasons such as economic crises in recent years, increased competition, reimbursement cuts, decreasing drug prices and profit ratio, and increasing operation costs. The main purpose of this study was to evaluate the financial status of community pharmacies in Çorum and to guide future sectoral financial studies.

Materials and Methods: One of the most commonly used method to evaluate the financial status and performance of companies is the "ratio analysis method". This ratio analysis has been conducted by accounting that data of 51 of the 93 community pharmacies operating in Çorum city.

Results: Considering the results of the ratio analysis in general, the pharmacies in Çorum have liquidity problems. More than half of the pharmacies could not pay their short-term debts with their current assets in the years mentioned in the study. Community pharmacies take more debit/credit to pay their short-term debts. The debit burden of the pharmacies has increased in the years mentioned in the study. Pharmacies have a low stock turnover ratio, and their inventory managements are insufficient.

Conclusion: It is seen that the main reason for the financial problems in community pharmacies is the low efficiency and productivity loss in resource management. It is thought that it would be beneficial to provide financial management training at the undergraduate level in the faculties of pharmacy and to provide vocational trainings within the Turkish Pharmacists' Association (TEB). In addition, an effective accounting system for community pharmacies should be prepared and implemented together by the TEB and relevant institutions.
\end{abstract}

Key words: Community pharmacy, Çorum, financial ratios, pharmacy management, Turkey

öz

Amaç: Toplum eczaneleri son yıllarda yaşanan ekonomik krizler, artan rekabet, geri ödeme kesintileri, artan işletme maliyetleri, düşen ilaç fiyatları ve kar oranları gibi nedenlerden dolayı finansal zorluklarla karşı karşıyadır. Bu çalıșmanın temel amacı, Çorum'daki toplum eczanelerinin mali durumunu değerlendirmek ve gelecekteki sektörel mali çalışmalara rehberlik etmektir.

Gereç ve Yöntemler: Şirketlerin finansal durumu ve performansı hakkında değerlendirmede en yaygın olarak kullanılan yöntemlerden biri “oran analizi yöntemi"dir. Bu analiz, Çorum ilinde faaliyet gösteren 93 toplum eczanesinin 51'ine ait muhasebe verileriyle gerçekleștirilmiştir.

Bulgular: Genel olarak oran analizi sonuçları dikkate alındığında, Çorum'daki toplum eczanelerinde likidite sorunları bulunmaktadır. Eczanelerin yarısından fazlası kısa vadeli borçlarını mevcut varlıkları ile ödememiştir. Toplum eczaneleri kısa vadeli borçların ödenmesinde daha fazla borç/ kredi kullanmaktadır. Çalışmada belirtilen yıllarda eczanelerin borç yükü artmıştır. Eczanelerin stok devir hızı düșüktür ve stok yönetimi yetersizdir. Sonuç: Toplum eczanelerinin mali sorunlarının temel nedeninin kaynak yönetimindeki düșük verimlilik ve verimlilik kaybı olduğu görülmektedir. Eczacılık fakültelerinde lisans düzeyinde ve Türk Eczacıları Birliği (TEB) bünyesinde mesleki eğitimlerde finans yönetimi eğitimi verilmesinin yararlı olacağı düşünülmektedir. Ayrıca, TEB ve ilgili kurumlar tarafından Toplum Eczaneleri için etkili bir muhasebe sistemi hazırlanmalı ve uygulanmalıdır. Anahtar kelimeler: Toplum eczanesi, Çorum, finansal oranlar, eczane yönetimi, Türkiye 


\section{INTRODUCTION}

Community pharmacies have excellent medical facilities that are mostly accessed by patients.' Literature evidence over the past 30 years has shown that pharmacy performance is a critical factor in the success of the healthcare system and that it creates a significant improvement in the health outcomes of the community. These are direct pharmaceutical service providers that offer a wide range of services and simultaneously use many limited healthcare resources. ${ }^{2,3}$ Healthcare services are one of the largest and fastest growing industries in the world. In developed countries, an average of $15 \%$ of health spending is allocated to drug expenditures. ${ }^{4}$ The increasing demand of community pharmacy customers has strengthened the health system all over the world. Therefore, it seems necessary to evaluate the financial performance of this industry to ensure that limited resources are spent for the best benefits. ${ }^{5}$ For community pharmacies, financial management is a dynamic process that requires adapting to the changes of the economic environment and other organizations. Thus, they could be more effective in the future and reach the strategic goals of the organization. ${ }^{6,7}$ At present, community pharmacy is going through a very difficult process as it is exposed to daily financial constraint and economic pressures. ${ }^{8}$ A community pharmacy must have adequate funds and manage them, ensuring its financial stability to fulfill its obligations and normally survive. Inputs make up most of the costs in providing pharmaceutical care in a community pharmacy. The difference between costs and revenues is the profit of the community pharmacy. Working order is required to ensure proper functioning of the community pharmacy. 9,10 Despite the difficulties it faces, it should continue its community pharmacy operations and survive in the future."

For pharmacies to survive in a healthier way, their financial structure must be strong. One of the most commonly used methods in the financial structure analysis is ratio analysis. Ratio analysis is calculated using the data in the financial statements of the companies. In this method, the relationships between the data forming the financial statements are examined. ${ }^{12}$ Financial ratios allow companies to compare both their status over the years and to other companies in the sector. ${ }^{13-17}$ While interpreting the results obtained from the ratio analysis calculation, the situation of the company and the sector should be considered.

There are four subgroups in the ratio analysis method (Table 1). The first group is liquidity ratios. The liquidity ratio analysis examines the liquidity status of the companies, the adequacy of the company's capital, and the power to pay the company's short-term debits. ${ }^{14}$ There are turnover ratios in the second group. The turnover ratios examine how effectively the business uses its assets. ${ }^{15}$ The third group is leverage ratios. In this group, the source structure of the businesses is examined. The effectiveness of the businesses in resource use is investigated. 16 Profitability ratios are included in the fourth and last group. With profitability ratios, it is examined whether the profits obtained from all operations of the business are sufficient or not. ${ }^{17}$
The biggest customer of the community pharmacies in Turkey is Social Security Institution (SGK). Since most community pharmacies have contracts with SGK, they are less affected by economic crises than other retail sectors are. SGK payments are made regularly within the period specified in the contract. However, environmental factors, such as gradual profit ratio applied in the recent years, decreasing profitability, and price decreases in stock products and increasing costs, pose financial problems for community pharmacies. In addition, factors such as the fact that pharmacists do not know financing management and how to use their cash and capital in other sectors weakens the financial structures of these companies. When community pharmacies manage financial assets and resources effectively and efficiently, they may continue their operations and look to the future with confidence.

\section{MATERIALS AND METHODS}

In the study, 16 ratios covering five-year (2015-2019) liquidity, turnover, leverage, and profitability ratios were analyzed in four groups. Community pharmacies' accounting data were used which are operating in the central district of Çorum. Community pharmacies that do not want to give data (22 pharmacies), whose data were not reliable (six pharmacies), and that have been operating for less than five years (14 pharmacies) were not included in the study. For this reason, 51 of 93 pharmacies, from which we could obtain reliable data, were used in the study. Absence of a sector with a similar structure to make comparisons in Istanbul Stock Exchange, the absence of a similar study to this study conducted in other provinces or in Turkey, in general, and the fact that the accounting system of the community pharmacies is not effective, are the limitations of this study. These restrictions constitute an obstacle to the comparison of results obtained in the study and to comment on the overall situation of Turkey. The comments and the suggestions made were based on the data of pharmacies included in the study. Ethics committee approval was received from Non-Interventional Research Ethics Committee of Hitit University (05.11.2020/2020-113). No statistical analysis was used in the study.

\section{RESULTS AND DISCUSSION}

According to the data obtained from the 51 community pharmacies included in the study, "Average Liquidity Ratio of the Sector" is given by years in Table 2 .

According to the data obtained from Table 3, most pharmacies cannot pay their short-term debits with their current assets for the year 2015. When the current ratios of the year 2015 were analyzed, it was determined that 18 pharmacies had values above the average, five pharmacies were close to the average, and the remaining 28 pharmacies had below-average values. The results for the year 2016 are like those for 2015. In 2017, there was an increase in the number of pharmacies whose current situation deteriorated. The number of pharmacies, which remained below the average in 2018, increased in 2017. Although there was a decrease in the number of pharmacies 
that remained below the average in 2019, it was determined that, as in previous years, more than half the pharmacies could not pay their short-term debits with their current assets.

When the acid test ratio was analyzed, it was determined that in the year 2015, 18 pharmacies had values above average, 8 pharmacies were close to the average, and 25 pharmacies had values below average (Table 3 ). Acid test ratio is a more sensitive ratio compared to the current ratio. Short-term debt payment power is investigated by reducing inventories that take time to sell from current assets. ${ }^{18}$ According to these results, it is seen that more than half of the pharmacies do not have the power to pay the short-term debt. This situation may be explained by the fact that pharmacies switched their purchases from long-term to short-term. In 2016, there were not many changes compared to 2015. In 2017, there was an increase in the number of pharmacies that remained below the average compared to the previous year. In 2018, there was a decrease in the number of pharmacies in a poor condition compared to the year 2017. However, an increase in the number of pharmacies below the average was determined in 2019.

When the liquid ratio of the pharmacies was analyzed by years, it was determined that in 2015, 18 pharmacies had values above average, 7 pharmacies were close to the average, and 26 pharmacies had values below average (Table 3 ). Liquid ratio is the ratio that determines the most sensitive situation among the liquidity ratios. This ratio shows the short-term debt payment power only with cash and similar assets. ${ }^{19}$ It was determined that more than half of the pharmacies had cash problems while paying their short-term debts in 2015. In 2016, there was an increase in the number of pharmacies having cash shortage compared to 2015. In 2017, there was a decrease in the number of pharmacies with an average ratio, while there was an increase in the ones above average. In 2018, there was an increase in the number of pharmacies that had cash problems. In 2019, the situation remained almost the same compared to the year 2018.

According to the data obtained from the 51 community pharmacies included in the study, "Sector Average of Operating Ratio" is given by years in Table 4.

When the accounts receivable turnover ratio was examined, it was determined that 13 pharmacies had values above the average, 8 pharmacies were close to the average, and 30 pharmacies had values below average in 2015 (Table 5). The higher the turnover ratio, the better it is for a company. ${ }^{20}$ Since the maturity given to its customers gradually decreases, it may collect more in a year. According to these data, more than half of the pharmacies make more deferred payment sales than average. This may be explained by the fact that cash sales of

\section{Table 1. Ratios used in ratio analysis method ${ }^{17}$}

\begin{tabular}{llll} 
Liquidity ratios & Turnover ratios & Leverage ratios & Profitability ratios \\
\hline Current ratio & Account receivable turnover ratio & Financial leverage ratio & Gross profit ratio \\
\hline Acid test ratio & Account receivable days & Equity to debt ratio & Net profit ratio \\
\hline \multirow{2}{*}{ Liquid ratio } & Stock turnover ratios & Shor-term debt to debt ratio & Return on assets \\
\cline { 2 - 3 } & Stock days & & Return on equity \\
\cline { 2 - 3 } & Debtor turnover ratios & & \\
\cline { 2 - 4 } & Debtor days & &
\end{tabular}

Table 2. Average liquidity ratio of pharmacies by years

\begin{tabular}{llllll} 
Liquidity ratios & 2015 & 2016 & 2017 & 2018 & 2019 \\
\hline Current ratio & 4,65637037 & 4,132142857 & 3,547741935 & 3,957096774 & 3,736451613 \\
\hline Acid test ratio & 3,410740741 & 3,350357143 & 2,902258065 & 2,483870968 & 2,168709677 \\
\hline Liquid ratio & 1,435888889 & 1,080357143 & 0,728064516 & 0,649677419 & 0,669548387 \\
\hline
\end{tabular}

Table 3. Distribution of pharmacy liquidity ratios by years

\begin{tabular}{|c|c|c|c|c|c|c|c|c|c|}
\hline \multirow{2}{*}{ Years } & \multicolumn{3}{|c|}{ Pharmacy distribution by current ratios } & \multicolumn{3}{|c|}{ Pharmacy distribution by acid test ratios } & \multicolumn{3}{|c|}{ Pharmacy distribution by liquid ratios } \\
\hline & $<\mathrm{A}$ & A & $A<$ & $<A$ & A & $A<$ & $<A$ & A & $A<$ \\
\hline 2015 & 28 & 5 & 28 & 25 & 8 & 18 & 26 & 7 & 18 \\
\hline 2017 & 31 & 0 & 20 & 31 & 2 & 18 & 30 & 1 & 20 \\
\hline
\end{tabular}


pharmacies that make deferred payment sales are lower than the other pharmacies. Pharmacies increasing the cash sales levels will decrease average collection times. In 2016, there was a serious decrease in the number of pharmacies below the average compared to the year 2015. In 2017, pharmacies remained almost the same as in the previous year. It is believed that the cash sales of the pharmacies included in the study increased in 2016 and 2017. While there was an increase in the number of the pharmacies below the average in 2018, it is thought that there was a serious decrease in the cash sales of pharmacies in 2019.

When the account receivable day was analyzed, it was determined that 25 pharmacies had above-average values, 10 pharmacies were close to the average, and 16 pharmacies had below-average values (Table 5 ). While there was a small increase in the number of pharmacies below the average in 2016 compared to the year 2015, there was a significant increase in the pharmacies below average in 2017. As in previous years, the increase in the number of pharmacies below average continued in 2018. In 2019, unlike previous years, there was a significant increase in pharmacies above the sector average, and there was a decrease in those below the sector average. It is believed that the ratio of pharmacies' credit sales to total sales affects the debt collection periods.

When the stock turnover ratios of 2015 were examined, it was determined that 17 pharmacies had values above average, 9 pharmacies were close to average, and 25 pharmacies had values below average (Table 5 ). The stock turnover ratio shows how many times the business renews its stocks in a year. ${ }^{21}$ In 2015, most pharmacies had a low stock turnover ratio. In 2016, there was a little increase in the number of pharmacies below average compared to the year 2015. In 2017, the situation remained the same compared to 2016. In 2018, the number of pharmacies below average decreased slightly, while those above average increased. In 2019, almost the same results were achieved compared to 2018. Pharmacies with a low stock turnover ratio are thought to bear an unnecessary inventory cost and do not behave carefully when buying goods.

When the stock days of 2015 were analyzed, it was determined that 16 pharmacies had values above average, 12 pharmacies were close to the average, and 23 pharmacies had values below average (Table 5). In 2016, there was a slight increase in the number of pharmacies, which remained below average compared to 2015. The situation like 2016 occurred in 2017. In 2018 , there was an increase in the number of the pharmacies above average compared to 2017. In 2019, there was a decrease in pharmacies above the sector average compared to 2018. The stock days and the stock turnover ratio of the pharmacies in 2015-2019 are in line with each other. Pharmacies' inventory management is thought to be insufficient.

When the debtor turnover ratio of 2015 was examined, it was determined that 14 pharmacies had values above average, 6 pharmacies were close to average, and 31 pharmacies had values below average (Table 5). The high ratio of this is an indication that the company may have trouble while paying debt. ${ }^{21}$ According to the data of 2015, most pharmacies did not

Table 4. Sector average of pharmacies' turnover ratios by years

\begin{tabular}{llllll} 
Turnover ratios & 2015 & 2016 & 2017 & 2018 & 2019 \\
\hline Account receivable turnover ratio & 647 & 4.595 & 4.643 & 5.131 & 6.417 \\
\hline Account receivable days & 77.532 & 79.781 & 95.467 & 98.805 & 7.246 \\
\hline Stock turnover ratios & 8.501 & 14.428 & 12.141 & 9.277 & 71.363 \\
\hline Stock days & 71.901 & 83.784 & 14.504 & 28.707 & 9.247 \\
\hline Debtor turnover ratios & 26454.236 & 6435.872 & 72.903 & 63.529 & 67.466
\end{tabular}

Table 5. Distribution of pharmacy turnover ratios by years

\begin{tabular}{|c|c|c|c|c|c|c|c|c|c|c|c|c|c|c|c|c|c|c|}
\hline Years & \multicolumn{3}{|c|}{$\begin{array}{l}\text { Account receivable } \\
\text { turnover ratio }\end{array}$} & \multicolumn{3}{|c|}{$\begin{array}{l}\text { Pharmacy } \\
\text { distribution by } \\
\text { account receivable } \\
\text { days }\end{array}$} & \multicolumn{3}{|c|}{$\begin{array}{l}\text { Pharmacy } \\
\text { distribution by stock } \\
\text { turnover ratios }\end{array}$} & \multicolumn{3}{|c|}{$\begin{array}{l}\text { Pharmacy } \\
\text { distribution by stock } \\
\text { days }\end{array}$} & \multicolumn{3}{|c|}{$\begin{array}{l}\text { Pharmacy } \\
\text { distribution by } \\
\text { debtor turnover } \\
\text { ratios }\end{array}$} & \multicolumn{3}{|c|}{$\begin{array}{l}\text { Pharmacy } \\
\text { distribution by } \\
\text { debtor days }\end{array}$} \\
\hline 2015 & 30 & 18 & 13 & 16 & 10 & 25 & 25 & 9 & 17 & 23 & 12 & 16 & 31 & 6 & 14 & 27 & 5 & 19 \\
\hline 2016 & 18 & 15 & 18 & 19 & 10 & 22 & 28 & 5 & 18 & 28 & 8 & 15 & 33 & 6 & 12 & 25 & 6 & 20 \\
\hline 2018 & 23 & 11 & 17 & 31 & 5 & 15 & 26 & 3 & 22 & 25 & 5 & 21 & 35 & 1 & 15 & 26 & 1 & 24 \\
\hline 2019 & 35 & 2 & 14 & 19 & 4 & 28 & 25 & 5 & 21 & 26 & 7 & 18 & 28 & 4 & 19 & 26 & 4 & 21 \\
\hline
\end{tabular}

A: Average 
encounter this problem. In 2016, the situation was like that of 2015. In 2017, there was a decrease in the number of the pharmacies below average and an increase in the number of those above average compared to 2016. There was an increase in the number of pharmacies below average in 2018 compared to 2017. In 2019, compared to 2018, the number of pharmacies below the sector average decreased, and the number of pharmacies above it increased.

When debtor day - that is, due dates, one of the main activities of the pharmacy - of 2015 was analyzed, it was determined that 19 pharmacies had values above average, 5 pharmacies were close to the average, and 27 pharmacies had values below average (Table 5). While 2015 and 2016 show similarities, in 2017 , there was an increase in the number of pharmacies above average, and a decrease in those below average. In 2019, there was a small decrease in the number of pharmacies above the sector average compared to 2017 and 2018.

According to the data obtained from the 51 community pharmacies included in the study, "Leverage Ratios Sector Average" is given by years in Table 6 .

When financial leverage ratios of 2015 were analyzed, it was determined that 31 pharmacies had values above average, 3 pharmacies were close to the average, and 17 pharmacies had values below average (Table 7 ). The financial leverage ratio is a ratio that shows the debt burden in the funds of the business. The fact that it is high indicates that the debts of the business increased. ${ }^{22}$ It is believed that more than half of the pharmacies use debit/credit. In 2016, the number of pharmacies below average increased compared to 2015. In 2017 and 2018, there was an increase in the number of pharmacies above average. There was a decrease in the number of the pharmacies above average in 2019 compared to 2018. It is an expected situation that pharmacies who have a cash shortage (Table 3 ) in the payment of short-term debts will use more debt.
When the equity to debt ratio of 2015 was analyzed, it was determined that 29 pharmacies had values above average, 8 pharmacies were close to the average, and 14 pharmacies had values below average (Table 7). Equity to debt ratio is found by dividing the debt by equity. The higher this ratio, the more the company's debt burden. ${ }^{21}$ The debt burden of more than half of the pharmacies increased. The number of pharmacies above average continued to increase in 2016, 2017, 2018, and 2019. These data are compatible with the financial leverage ratios.

When the short-term debt to debt ratio of 2015 was examined, it was determined that 29 pharmacies had values above average, 6 pharmacies were close to the average, and 16 pharmacies had values below the average (Table 7). The weight of the short-term part of the debts is calculated at the short-term debt to debt ratio. This high ratio indicates that the company may face liquidity shortage. A short-term debt burden of more than half of the pharmacies is high. This situation explains the cash shortage in the payment of short-term debt and the use of debit/credit. In 2016, there was a decrease in the number of pharmacies below average compared to 2015. The number of pharmacies with a high debt burden increased in 2017 and 2018 compared to 2016. In 2019, the number of the pharmacies with high short-term debt burdens decreased compared to 2018. It is thought that the burden of short-term debts was reduced with the use of more debit/loans. In a survey conducted by Turkish Pharmacists' Association (TEB) in 2019, in Turkey, $57 \%$ of pharmacists stated that they used credit. ${ }^{23}$

According to the data obtained from the 51 community pharmacies included in the study, "Profitability Ratios Sector Average" is given by years in Table 8.

When the gross profit ratio of 2015 was analyzed, it was determined that 16 pharmacies had values above average, 23 pharmacies were close to the average, and 12 pharmacies had values below the average (Table 9). High gross profit ratio indicates that the company's purchase cost has decreased. ${ }^{24}$

Table 6. Leverage ratio sector averages of pharmacies by years

\begin{tabular}{llllll} 
Leverage ratios & 2015 & 2016 & 2017 & 2018 & 2019 \\
\hline Financial leverage ratio & 2.315 & 1.946 & 2.350 & 2.925 & 2.602 \\
\hline Equity to debt ratio & 2043.093 & 1968.811 & 4.771 & 5.363 & 4.580 \\
\hline Shor-term debt to debt ratio & 1045.392 & 798.924 & 4244.861 & 4142.701 & 4727.976 \\
\hline
\end{tabular}

Table 7. Leverage ratio distribution of pharmacies by years

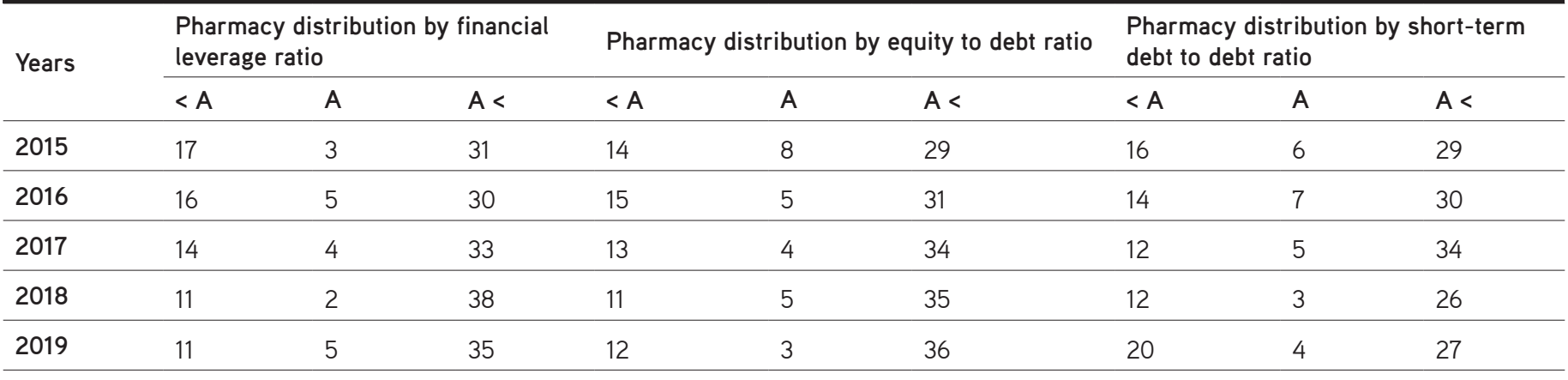

A: Average 
Most pharmacies have an average and above-average gross profit ratio. While the number of pharmacies with low profit margins increased slightly in 2016 and 2017, this situation improved in 2018 and 2019. It is thought that the profit ratio varies due to the discount ratio in the sales of the pharmacies and the distribution of imported/domestic drugs.

When the net profit ratio of 2015 was examined, it was determined that 12 pharmacies had values above average, 25 pharmacies were close to average, and 14 pharmacies had values below average (Table 9). High net profit ratio indicates that the productivity of companies has increased. ${ }^{25}$ In this case, most pharmacies have a net profit ratio close to the sector average. In 2016 and 2017, the number of pharmacies above average increased compared to 2015. This situation may also be explained by the distribution of imported/domestic drugs in sales. In 2018 and 2019, there was not much change in the above-average and near-average pharmacies. Although most pharmacies continue their operations with an average and above-average net profit ratio, the fact that they experience cash and short-term debt payment difficulties and that they use debit/loans suggest that they are not financially well managed.

When return on assets (ROA) of 2015 was examined, it was determined that 25 pharmacies had values above average, 12 pharmacies were close to the average, and 14 pharmacies had values below the average (Table 9). ROA shows how effective the assets of companies are in generating profit. ${ }^{26}$ More than half of the pharmacies manage their assets successfully. While there was not much change in 2016 compared to 2015, there was an increase in the number of below-average pharmacies in 2017. In 2018, there was an increase in the number of pharmacies close to the average. In 2019, with 13 pharmacies below-average, a better situation was found out than those in previous years.

When return on equity (ROE) of 2015 was examined, it was determined that 13 pharmacies had values above average, 24 pharmacies were close to the average, and 14 pharmacies had values below the sector average (Table 9). The ROE shows how much profit the partners have made in return for the capital they put in. ${ }^{22}$ If this ratio is high, the profit of the business is high too. In this case, half of the pharmacies achieve the same profitability as the average. While the number of pharmacies close to the average and above average increased in 2016, the number of pharmacies close to average and below average increased in 2017. In 2018 and 2019, there was a decrease in the number of pharmacies with a below-average condition. It is noteworthy that although more than half of the pharmacies have a good picture in terms of gross profit margin, net profit margin, ROA, and ROE, they are experiencing financial difficulties. Increasing costs are thought to cause financial difficulties.

Reasons such as absence of a sector to make comparisons in İstanbul Stock Exchange, the absence of a similar study to this study, and the fact that the accounting system of pharmacies is not effective constitute obstacles to compare the results. Because of these reasons, general comments cannot be made about the financial status of community pharmacies in Turkey.

\section{CONCLUSION}

Community pharmacies want to survive like other businesses. They strive to maintain and increase their current market share while surviving. For a business to increase its competitiveness, its financial structure must be strong.

Table 8. Profitability ratios sector averages of pharmacies by years

\begin{tabular}{|c|c|c|c|c|c|}
\hline Profitability ratios & 2015 & 2016 & 2017 & 2018 & 2019 \\
\hline Gross profit ratio & 0.920 & 0.877 & 0.761 & 0.676 & 0.823 \\
\hline Net profit ratio & 0.712 & 0.484 & 0.484 & 0.320 & 0.403 \\
\hline Return on assets & 0.902 & 1.043 & 0.935 & 0.953 & 0.828 \\
\hline Return on equity & 1.939 & 2.030 & 2.469 & 2.057 & 2.939 \\
\hline
\end{tabular}

Table 9. Profitability ratio distribution of pharmacies by years

\begin{tabular}{|c|c|c|c|c|c|c|c|c|c|c|c|c|}
\hline \multirow{2}{*}{ Years } & \multicolumn{3}{|c|}{$\begin{array}{l}\text { Pharmacy distribution by } \\
\text { gross profit ratio }\end{array}$} & \multicolumn{3}{|c|}{$\begin{array}{l}\text { Pharmacy distribution by net } \\
\text { profit ratio }\end{array}$} & \multicolumn{3}{|c|}{$\begin{array}{l}\text { Pharmacy distribution by } \\
\text { return on assets }\end{array}$} & \multicolumn{3}{|c|}{$\begin{array}{l}\text { Pharmacy distribution by } \\
\text { return on equity }\end{array}$} \\
\hline & $<A$ & A & $A<$ & $<A$ & A & $A<$ & $<A$ & A & $A<$ & $<A$ & A & $A<$ \\
\hline 2015 & 12 & 23 & 16 & 14 & 25 & 12 & 14 & 12 & 25 & 14 & 24 & 13 \\
\hline 2016 & 14 & 22 & 15 & 13 & 24 & 14 & 15 & 10 & 26 & 12 & 25 & 14 \\
\hline 2017 & 15 & 22 & 14 & 13 & 23 & 15 & 17 & 9 & 25 & 14 & 22 & 15 \\
\hline 2018 & 11 & 24 & 16 & 10 & 25 & 15 & 15 & 14 & 22 & 13 & 24 & 14 \\
\hline 2019 & 11 & 22 & 18 & 11 & 24 & 16 & 13 & 15 & 23 & 10 & 25 & 16 \\
\hline
\end{tabular}

A: Average 
As a result of the study based on the data obtained from community pharmacies, it is seen that these businesses prefer short-term debit/credit. This situation negatively affects the resource structure and cash situation of the business. It causes pharmacies to face liquidity shortage while paying their debts. When turnover ratios of the pharmacies are analyzed, the fact that the maturity given by them to their customers and the maturity given to them by the sellers are almost the same is increasing the importance of liquidity management for these businesses. For an effective financial structure to be formed, the existing financial structure needs to be changed. It is seen that most pharmacies in Çorum province are not effective in liquidity and resource management. This negatively affects the efficiency of commercial activities. The profitability situations of pharmacies generally move in the same direction.

It is thought that it would be beneficial to provide finance management training at the undergraduate level in the Faculties of Pharmacy and in vocational trainings within the TEB. In addition, an effective accounting system for community pharmacies should be prepared and implemented together by the TEB and relevant institutions.

Conflict of interest: No conflict of interest was declared by the authors. The authors are solely responsible for the content and writing of this paper.

\section{REFERENCES}

1. Malovecká I, Mináriková D, Foltán V. The change of demographic indicators, the legal form of the ownership, the owner share of a pharmacist in the capital and economic situation in the community pharmacies resulting from globalization. Soc Pharm Health Care. 2015;1:32-37.

2. Doucette WR, McDonough RP, Mormann MM, Vaschevici R, Urmie JM, Patterson BJ. Three-year financial analysis of pharmacy services at an independent community pharmacy. J Am Pharm Assoc. 2012; 52:181-187.

3. Vermeulen LC, Rough SS, Thielke TS, Shane RR, Ivey MF, Woodward BW, Pierpaoli PG, Thomley SM, Borr CA, Borr BS, Zilz DA. Strategic approach for improving the medication-use process in health systems: the high-performance pharmacy practice framework. Am J Health Syst Pharm. 2007;64:1699-1710.

4. Akortsu MA, Abor PA. Financing public healthcare institutions in Ghana. J Health Organ Manag. 2011;25:128-141.

5. Imani DA, Golestani M, Moghimi M, Janati A. Indicators in evaluating financial and economic performance of pharmacy: a systematic review. Value Health. 2016;19:A829.
6. McDonald R, Cheraghi-Sohi S, Sanders C, Ashcroft D. Professional status in a changing world: the case of medicines use reviews in English community pharmacy. Soc Sci Med. 2010;71:451-458.

7. Philip B, Weber RJ. Enhancing pharmacy practice models through pharmacists' privileging. Hosp Pharm. 2013;48:160-165.

8. Vogler S, Habimana K, Art D. Does deregulation in community pharmacy impact accessibility of medicines, quality of pharmacy services and costs? Evidence from nine European countries. Health Policy. 2014;117:311-327.

9. Herist N, Rollins B, Perri M. Financial Analysis in Pharmacy Practice. London: Pharmaceutical Press; 2011:48-49.

10. Malovecká I, Papargyris K, Mináriková D, Foltán V, Jankovská A. Prosperity of community pharmacy evaluated by gross and net profit and suggested corrective measures. 10 years study. Eur Pharm J. 2015;62:20-24.

11. Norris P, Horsburgh S, Sides G, Ram FJ. Geographical access to community pharmacies in New Zealand. Health Place. 2014;29:140-145.

12. Akdoğan N, Tenker N. Finansal Tablolar ve Mali Analiz Teknikleri. İstanbul: Lebib Yalkın Yayımlar ve Basım İşleri; 1997:526.

13. Ercan M, Ban ÜK. Finansal Yönetim. Ankara: Gazi Kitabevi; 2005:37.

14. Karapınar A, Zaif F. Finansal Analiz. Ankara: Gazi Kitabevi; 2009:149.

15. Türko M. Finansal Yönetim. İstanbul: Alfa Basım Yayım Dağıım; 1999:104.

16. Çetiner E. İşletmelerde Mali Analiz. Ankara: Gazi Kitabevi; 2005:145.

17. Akdoğan N, Tenker N. Finansal Tablolar ve Mali Analiz Teknikleri. Ankara: Gazi Kitabevi; 2006:606-634.

18. Sarıaslan H, Erol C. Finansal Yönetim Kavramlar, Kurallar ve İlkeler. Ankara: Siyasal Kitabevi; 2008:195.

19. Ceylan A, Korkmaz T. Finansal Yönetim Temel Konular. 9. baskı. Bursa: Ekin Yayınevi; 2005:48.

20. Akgüç Ö. Finansal Yönetim. 5. baskı. İstanbul: Muhasebe Enstitüsü Eğitim ve Araștırma Vakfı Yayınları; 1989:58.

21. Brealey RA, Myers SC, Marcus AJ. Principles of Corporatio Finance. New York: Mc Graw Hill Companies Inc; 2011:719-724.

22. Akdoğan N, Tenker N, Finansal Tablolar ve Mali Analiz Teknikleri, Ankara: Gazi Kitabevi; 2001:618-637.

23. Üzeyir F, Türker M, Albayrak ÖD. Eczanelerde Ekonomik Durum Ve Finansal Durum Araştırması. Ankara: Türk Eczacıları Birliği; 2019:30.

24. Jagels MG, Coltman MM. Hospitality Management Accounting. New York: Wiley; 2004:155.

25. Okka O. Finansal Yönetim Teori ve Çözümlü Problemler, Geliștirilmiș 6. Basım, Nobel Ankara: Akademik Yayıncılık; 2015:141.

26. Weaver SC. The Essentials of Financial Analysis. Boston: Mcgraw Hill Companies; 2012:64. 